International Journal of Research in Advent Technology, Vol.7, No.3, March 2019

E-ISSN: 2321-9637

Available online at www.ijrat.org

\title{
Bioaccumulation Potential And Speciation Of Arsenic Ions In Vigna Radiate Root Biomass Using Microwave Assisted Extraction By HPLC-ICP-MS
}

\author{
Anil Kumar Giri ${ }^{1}$ \\ ${ }^{I}$ Department of Environmental Science, Fakir Mohan University, Balasore, Odisha-756020, India \\ ${ }^{1}$ : Corresponding author. Tel.: +91-9439949398 \\ E-mail address: anilchemnit@gmail.com (A. K. Giri)
}

\begin{abstract}
Arsenic ions accumulation and speciation of Vigna radiate root biomass using microwave assisted extraction analysis has been studied. Plants were cultured in a synthetic water with modified $0.25 \mathrm{M}$ concentration of Hoagland's nutrient solution at $\mathrm{pH} 6.8$ supplemented with $0,3,5$, and $10 \mathrm{mg}$ As/L solution of $\mathrm{As}_{2} \mathrm{O}_{3}$. The maximum extraction efficiency of arsenic ions was found to be $85.14 \%$ from root biomass using $10 \%(\mathrm{v} / \mathrm{v})$ tetramethylammonium hydroxide solution at $30{ }^{\circ} \mathrm{C}$ for 30 minutes after 21 days. After treatment of plants then the root biomass was characterized using high performance liquid chromatography, inductively coupled plasma mass spectroscopy, scanning electron microscope and fourier-transform infrared spectroscopy technique.

Keywords: Microwave assisted extraction; Arsenic ions speciation; Vigna radiate; Inductively coupled plasma mass spectroscopy; Root biomass
\end{abstract}

\section{INTRODUCTION}

Heavy metal pollution by natural as well as anthropogenic activities is significant threats to the living and nonliving environment. Arsenic is one of the most hazardous metalloid pollutants which are emitted by natural and anthropogenic sources like biological activity, geochemical reactions, smelting of non-ferrous metals and burning of fossil fuels [12]. Arsenic exists in environment in both inorganic as well as organic forms. Inorganic arsenic can occur in the environment in several forms, e.g. metalloid arsenic As (0), arsenite $\left(\mathrm{AsO}_{3}{ }^{3-}\right)$ and arsenate $\left(\mathrm{AsO}_{4}{ }^{3-}\right.$ ). As (III), As (V), methylarsonic acid (MAA) and dimethylarsinic acid (DMA) are the predominant arsenic species found in green plants [3,4]. Chronic exposure to arsenic, particularly inorganic arsenite (As (III)) and arsenate (As (V)) has been implicated in many physiological disorders and various types of cancers. Therefore, World Health Organization (WHO) has recommended the maximum permissible limit of arsenic in drinking water as $10 \mu \mathrm{gL}^{-1}$ [5-6]. The major advantages of bioremediation technique are the environmentally friendly, cost-effective, aesthetically pleasing, technologically feasible, longterm applicability, and ecological aspect [7-8]. The extraction of arsenic ions from solid matrices is a critical process since high recoveries as well as species preservation are required. Speciation is generally accomplished in three steps: sample preparation, species separation and detection. Most of the speciation work done of different arsenic species in marine organism. Enzymatic digestion or methanol extractants with agitation and microwave heating extraction have been successfully used to extract the organic arsenic species [9-12]. The use of microwave radiation and high pressure allows to accelerate sample digestion and to minimize contamination and losses of volatile elements. Conventional extraction procedures as well as ultrasound assisted extraction with acids were used for the direct determination of trace elements in various plant samples by atomic absorption spectrometry. The extraction in an open system was performed with conc. HCL or diluted $\mathrm{HNO}_{3}$ for dissolution of $\mathrm{Al}, \mathrm{Ca}, \mathrm{Cd}, \mathrm{Cu}, \mathrm{Fe}, \mathrm{Mg}, \mathrm{Pb}$ and $\mathrm{Zn}$ from plant materials [13-16]. Microwave assisted extraction was applied mainly for elemental analysis of soils, sludge and sediments of metals in these materials. In plants, arsenite is strongly bound to -SH groups of cytosolic proteins and macromolecular constituents. Several comprehensive evaluations of techniques for extracting arsenic species from terrestrial plant samples have been reported [17-19]. In order to be applicable to risk assessment approaches to arsenic impacted sites, these methods need to be highly reproducible, rugged, and use instrumentation that is readily available, and cost effective, in commercial laboratories. The aim of the present study is (i) to evaluate the uptake of different arsenic ions (in the range of $\mathrm{mg} \mathrm{kg}^{-1}$ ) with different concentration by Vigna radiate root from aqueous solution, (ii) to evaluate the efficiency of extraction solution extracted arsenic ions using a complete microwave wet digestion process by ICP-MS. (iii) to evaluate extracted materials were characterized by HPLC, SEM-EDX and FTIR techniques to know the arsenic ions. 
International Journal of Research in Advent Technology, Vol.7, No.3, March 2019

\author{
E-ISSN: 2321-9637 \\ Available online at www.ijrat.org
}

\section{MATERIALS AND METHODS \\ 2.1. Experimental Procedure}

Vigna radiate dried matured seeds were collected from the Department of Plant Breeding and Genetics, Odisha University of Agriculture and Technology, Odisha, India. Seeds were treated with detergent solution and washed with running tap water for 15 min. Seeds were sterilized with $0.1 \%$ aqueous mercuric chloride solution for $20 \mathrm{~min}$ and were sown over plastic nets on glass trays $(12 \times 10 \times \mathrm{x} 8 \mathrm{~cm})$ (Borosil, India) containing the Hoagland nutrient solution. The ratio of the seeds and the solution used were 1:30. The trays were kept in a growth room temperature at $25 \pm 2^{\circ} \mathrm{C}$ under cool, white

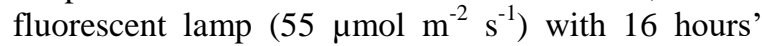
photoperiod. $\mathrm{pH}$ (Orion two star, USA) of the nutrient solution was adjusted to 6.8 using $0.1 \mathrm{~N} \mathrm{HCl}$ or $0.1 \mathrm{~N} \mathrm{KOH}$; the solution was changed regularly at 3 days' intervals to maintain the $\mathrm{pH}$. The concentrations were selected on the basis of preliminary experiment within a range that produced growth inhibition. Arsenic trioxide $\left(\mathrm{As}_{2} \mathrm{O}_{3}\right)$ was used as $\left[\left(0\right.\right.$ (control), 3,5 , and $\left.10 \mathrm{mgL}^{-1)}\right]$. The experiment was laid in a completely randomized block design with three replications. The length of the primary root and the shoot numbers were measured at $7^{\text {th }}$ day intervals from the date of root emergence up to the $28^{\text {th }}$ day. The rate of root length in each experiment was determined by subtracting the length of the root recorded on the day of germination from that noted on the $28^{\text {th }}$ day. The treated plants were harvested after 7, 14, 21 and 28 days. Deionised water was added daily to compensate the water loss through plant transpiration, sampling and evaporation. After completed test duration each plant with approximately fresh weight of $200 \mathrm{~g}$ having root length of 8 to $10 \mathrm{~cm}$ and shoot length of 10 to $12 \mathrm{~cm}$ were selected and analyzed for arsenic ions accumulation and toxicity. In addition, the residual arsenic ions in the solution were measured to assess the removal potential of Vigna radiate plant.

\subsection{Preparation Of Hoagland Nutrient Solution}

The modified 0.25 molar concentration of Hoagland nutrient solution consists of $4.0 \mathrm{mM} \mathrm{CaNO}_{3}, 2.0 \mathrm{mM}$ $\mathrm{MgSO}_{4}, 4.0 \mathrm{mM} \mathrm{KNO}_{3}, 0.4 \mathrm{mM}\left(\mathrm{NH}_{4}\right)_{2} \mathrm{SO}_{4}, 2 \mu \mathrm{M}$ $\mathrm{MnSO}_{4}, 0.3 \mu \mathrm{M} \mathrm{CuSO}_{4}, 0.8 \mu \mathrm{M} \mathrm{ZnSO}, 30 \mu \mathrm{M} \mathrm{NaCl}$,

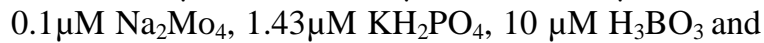
$20 \mu \mathrm{M}$ Fe-Na-EDTA (All obtained from Merck Specialties) in $1 \mathrm{~L}$ of double distilled water. The $\mathrm{pH}$ of the nutrient solution was adjusted to 6.8 using 0.1 $\mathrm{N} \mathrm{HCl}$ or $0.1 \mathrm{~N} \mathrm{KOH}$. The solution was changed regularly at three days' intervals to maintain the desired $\mathrm{pH}[20]$.

\subsection{Microwave Extraction Analysis Followed ICP-MS}

All reagents were of analytical-reagent grade.1M $\mathrm{HNO}_{3}$ (Merck, Germany), $1 \mathrm{M} \mathrm{HCl}$ (Merck, Germany) and $30 \% \mathrm{H}_{2} \mathrm{O}_{2}$ were applied for the preparation of the leaching solutions. In all experiments, double distilled water (Milli-Q Millipore $18.2 \mathrm{M} \Omega \mathrm{cm}^{-1}$ conductivity) was used for preparation, dilution and analytical purposes of solutions. A solution of 1000 $\mathrm{mgL}^{-1}$ of arsenite stock solution was prepared by dissolving $1.320 \mathrm{~g}$ of arsenic trioxide $\left(\mathrm{As}_{2} \mathrm{O}_{3}\right.$; Merck Chemicals, Germany) in deionized water containing $4 \mathrm{~g} \mathrm{NaOH}$ in $1 \mathrm{~L}$ of double distilled water. The stock solutions were preserved with $2 \%(\mathrm{v} / \mathrm{v})$ trace metal grade nitric acid. Subsequently, arsenite different working solutions of required concentrations were prepared by proper dilution. The $\mathrm{pH}$ was adjusted to the desired level with $0.1 \mathrm{~N} \mathrm{HCl}$ or $0.1 \mathrm{~N} \mathrm{KOH}$ solutions. Before use all lab ware was subjected to a cleaning procedure.

Microwave assisted wet digestion extraction processes were conducted with Shanghai Sineo MAS-II oven delivering a maximum power of 1000 $\mathrm{W}$. The microwave system was programmed to heat the sample to a specified temperature and maintained for a specified period. To optimize the microwaveassisted extraction of arsenic ions from root parts of plant material was conducted consisting of 3 heating temperatures $\left(40{ }^{\circ} \mathrm{C}, 60{ }^{\circ} \mathrm{C}\right.$ and $\left.80{ }^{\circ} \mathrm{C}\right)$ and heating times of 5, 15 and 25 minutes for each of the 2 different extraction solutions. The two extracting solutions were used i.e. $10 \%$ (v/v) tetramethylammonium hydroxide (TMAH) and a modified protein extracting solution. Arsenic ions containing dried Vigna radiate root powder (0.5 g) was weighed into a $50 \mathrm{~mL}$ reaction vessels to which $10 \mathrm{~mL}$ of concentrated nitric acid was added. The digested mixture was heated at $60{ }^{\circ} \mathrm{C}$ for $30 \mathrm{~min}$ and filtered into a volumetric flask with the help of Whatman 42 filter paper [10]. After complete digestion to each sample was added $10 \mathrm{~mL}$ extractant solution. The microwave system was programmed to heat the sample to a specified temperature, and the temperature was maintained for a specified period. After microwave heating, the samples were allowed to cool to room temperature. The flasks were allowed to cool to room temperature and made up to a final volume $(10 \mathrm{~mL})$ with deionized water. To measure arsenic ions concentration in digested samples, $1 \mathrm{~mL}$ of digest was mixed with $9 \mathrm{~mL}$ of reducing solution consisting of $1.5 \%(\mathrm{w} / \mathrm{v})$ potassium iodide, $1.5 \%$ (w/v) ascorbic acid and 10\% (v/v) hydrochloric acid. 
International Journal of Research in Advent Technology, Vol.7, No.3, March 2019

E-ISSN: 2321-9637

Available online at www.ijrat.org

This mixture was then heated at $40{ }^{\circ} \mathrm{C}$ for $1 \mathrm{~h}$. Arsenic ions were determined by ICP-MS (model PE ELAN 6000, Perkin-Elmer, USA). The carrier solution was $10 \%(\mathrm{v} / \mathrm{v})$ hydrochloric acid, and the reductant solution consisted of $0.2 \%(\mathrm{w} / \mathrm{v})$ sodium borohydride and $0.05 \%(\mathrm{w} / \mathrm{v})$ sodium hydroxide. The carrier solution was $1 \%(\mathrm{v} / \mathrm{v})$ nitric acid; samples were made up in solution of $10 \mu \mathrm{g}$ rhodium $\mathrm{L}^{-1}$ which served as an internal standard [21-22]. All data were expressed as mean \pm SEM of three separate experiments. The mean of metal ions concentration was calculated using MINITAB.

\subsection{Arsenic Ions Speciation Using HPLC}

Arsenic ions speciation of Vigna radiate root biomass during absorption process was observed with the help of high performance liquid chromatography (Hamilton PRP-X100 anion-exchange column chromatogram). Dry $0.5 \mathrm{~g}$ arsenic containing samples were extracted using microwave assisted digestion with $5 \mathrm{~mL}$ of 1:1 methanol/water for 2 hours. The samples were centrifuged then the the supernatant was decanted into a $50 \mathrm{~mL}$ volumetric flask. The procedure was repeated with the residual pellet and the two extracts were combined. The residue was rinsed three times with $5 \mathrm{~mL}$ of water, and all supernatants were combined. Mobile phase was 20 $\mathrm{mM}$ ammonium phosphate $\left(\mathrm{NH}_{4} \mathrm{H}_{2} \mathrm{PO}_{4}\right)$ buffer at $\mathrm{pH}$ 6.0 and flow rate $1.5 \mathrm{mLmin}^{-1}$.

\section{RESULTS AND DISCUSSION \\ 3.1. Extraction Efficiency Of Arsenic Ions}

Extraction is an important step for separation of constituents from the plant material. Microwave digestion technique is a simple, inexpensive and valuable tool used in applied chemistry which requires lesser amount of solvent, simplified manipulation and higher purity of final product with lower cost. Microwave extraction is becoming the choice for the extraction of solid matrices for organic analyte analysis by ICP-MS techniques. In the present study, extraction of arsenic ions from Vigna radiate root biomass using $10 \%$ (v/v) tetramethylammonium hydroxide (TMAH), and a modified protein extracting solution has been conducted at three different temperatures for three different times after 21 days of experiment and the results are presented in Figure 1a and Figure $\mathbf{1 b .}$

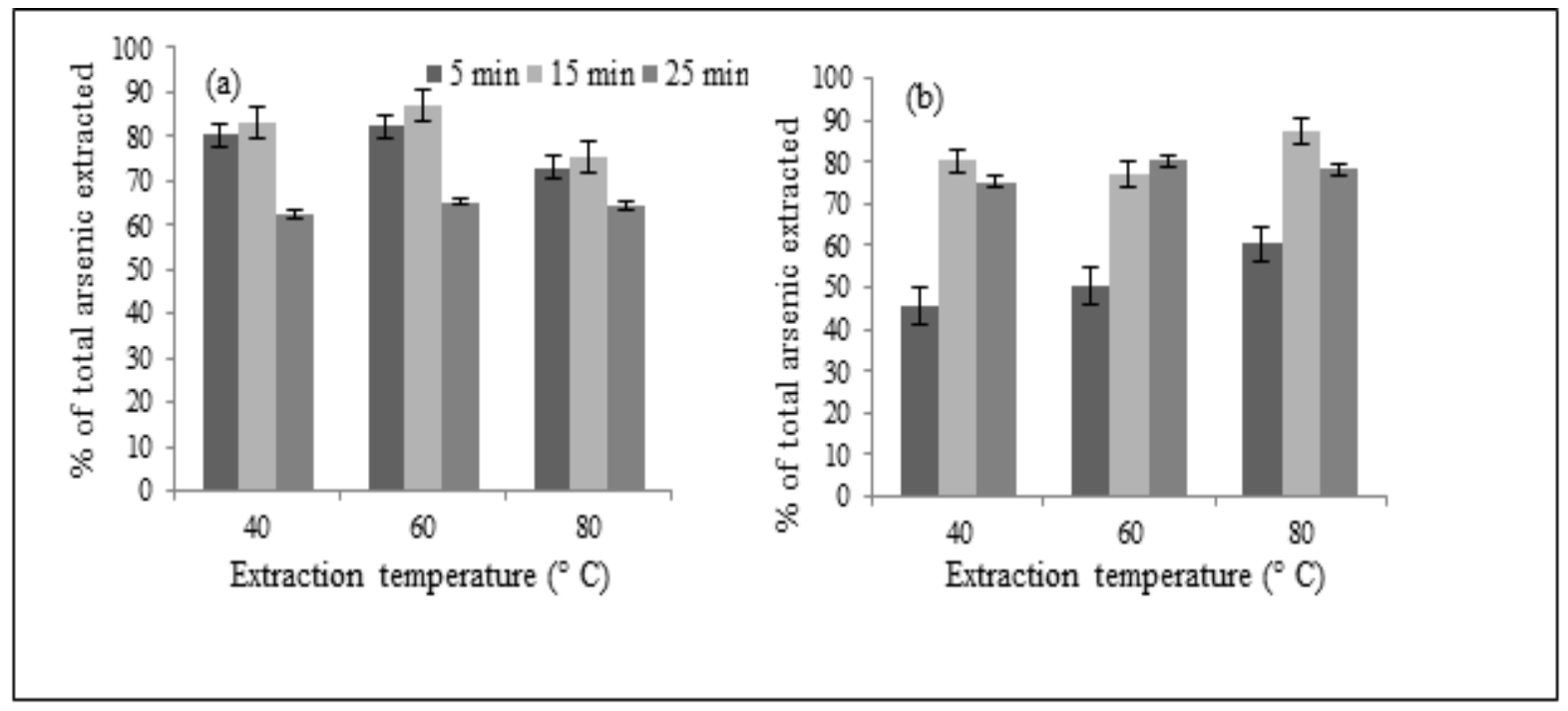

Figure 1. Arsenic ions extraction efficiency for Vigna radiate root biomass using (a) modified protein extracting solution, (b) 10\% TMAH after 21 days' experiment. Data represents the mean \pm S.D ( $n=3$, "n" stands for the number of experiment replicates.

The efficiency of the extraction of arsenic ions increased with increasing temperature in modified protein extracting solution at all concentration of arsenite. In tetramethylammonium hydroxide extracting solution efficiency increased with increase in temperature with the highest value at a temperature of $60{ }^{\circ} \mathrm{C}$ after $21^{\text {th }}$ days experimentation in treated with $5 \mathrm{mg} / \mathrm{L}$ arsenite solution. It is evident that at high temperature tetramethylammonium hydroxide (TMAH) is expected to break down the strong As-SH (thiol) bonds present in plant cells. For arsenic ions accumulation once inside the plant must be translocated through the cytoplasm /vacuoles of adjacent cells at high concentrations and that does not disrupt cytoplasmic function. The electrochemical species of arsenic ions changed in different forms in 


\section{Available online at www.ijrat.org}

the plant shoot tissue. Sulfhydryl enzymes enhanced electrochemically oxidize in plant tissue of arsenite to arsenate. The bacterial arsenate reductase (ArsC) catalyzes the electrochemical reduction of arsenate to arsenite. The bacterial $\gamma$-glutamylcysteinesynthetase $(\gamma$-ECS) catalyzes the formation of $\gamma$ glutamylcysteine $(\gamma$-EC) from the amino acids glutamate and cysteine and is the committed step in the synthesis of glutathione (GSH) and phytochelatine (PCs) (indicated by three arrows) [18, $24,19]$. Reduced arsenite can bind organic thiols
(RS) such as those in $\gamma$ - EC, GSH, and PCs through the replacement of oxygen by organic sulfur species. The scheme of reaction mechanism is presented in Figure 2. Metal ions penetrated plants by passive process, mostly by exchange of cations which occurred in the cell wall. All heavy metals were taken up by plants through absorption, translocation and released by excretion. It can be proposed that the roots reached saturation during the period and there exists some mechanism in roots that could detoxify heavy metals or transfer them to aerial parts [25-29].

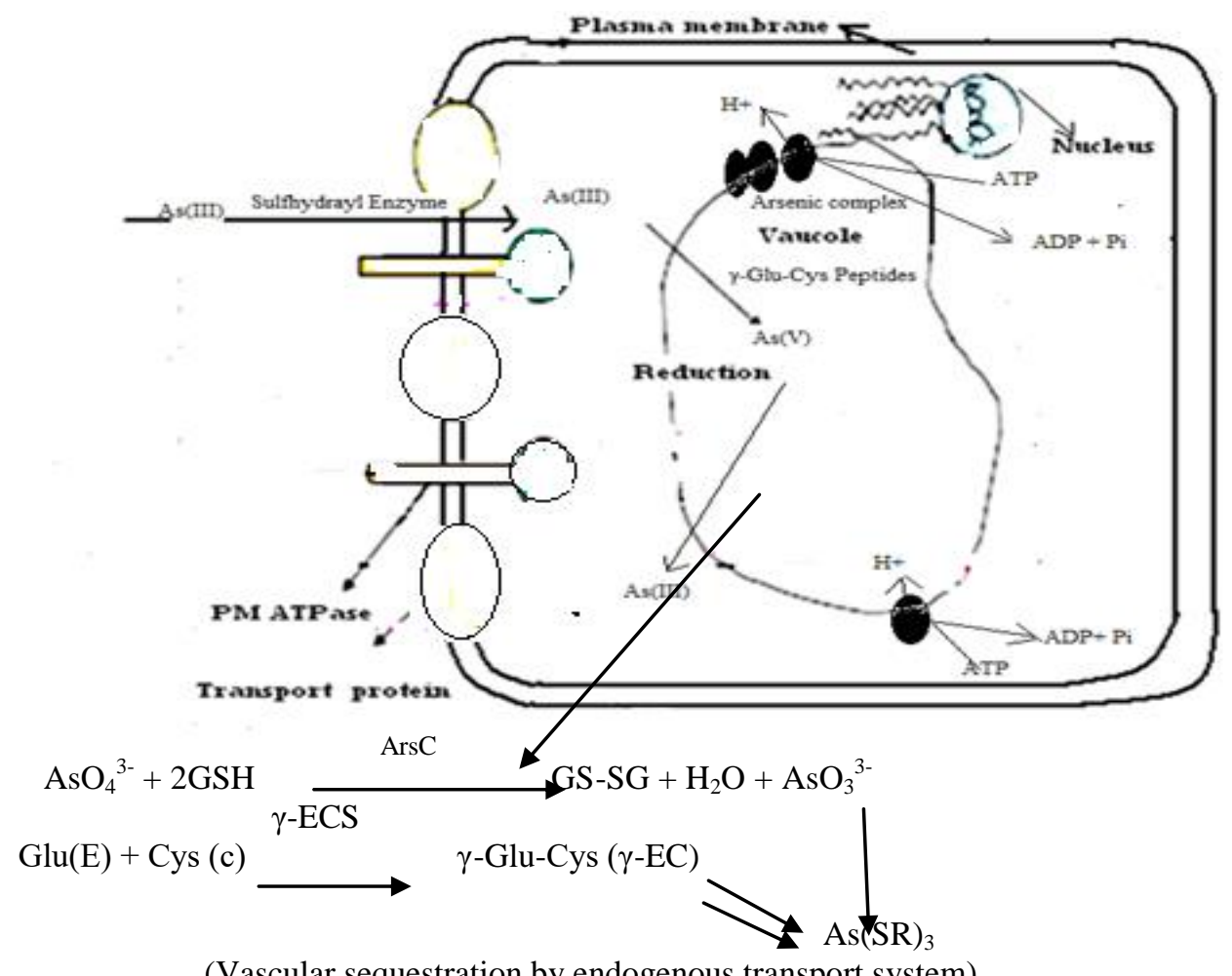

(Vascular sequestration by endogenous transport system)

Figure 2. Hypothetical model and reaction mechanism of arsenic ions changed in different forms in Vigna radiate root tissue.

\subsection{Stability And Speciation Of Arsenic Ions}

Arsenic species were separated on the Hamilton PRP x 100 anion-exchange column. In present study, the plant material was used to evaluate the stability of arsenic species during the extraction procedure. Therefore, the method adopted in this study was tested on root biomass of Vigna radiate extracted by $10 \%(\mathrm{v} / \mathrm{v})$ tetramethylammonium hydroxide (TMAH) with yield of $85.14 \%$, and extracted by a modified protein extracting solution with yield of $88.92 \%$. Chromatograms are obtained for arsenic species in plant root biomass with modified protein extraction and TMAH extract solution by using HPLC after 21 days' experiment and results are shown in Figure 3a and Figure 3b. Vigna radiate root biomass reveals maximum amount of inorganic arsenic species and very less amount of organic arsenic species consists as it is indicated from the above figures. Arsenic (III) are present in maximum quantity, arsenic (V) in minimum quantity and the organic arsenic like monomethylarsonic (MMA) and dimethylarsinic acid (DMA) are very less at $5 \mathrm{mg} / \mathrm{L}$ in different experimentation days and results are presented in Table 1. Recent studies have described the formation of As-phytochelatin complexes in several terrestrial plants upon exposure to arsenate. Phytochelatins (PCs) are thiol (SH) - rich peptides derived from glutathione (GSH) and are considered to be involved in the mechanism of detoxifying heavy metals in 


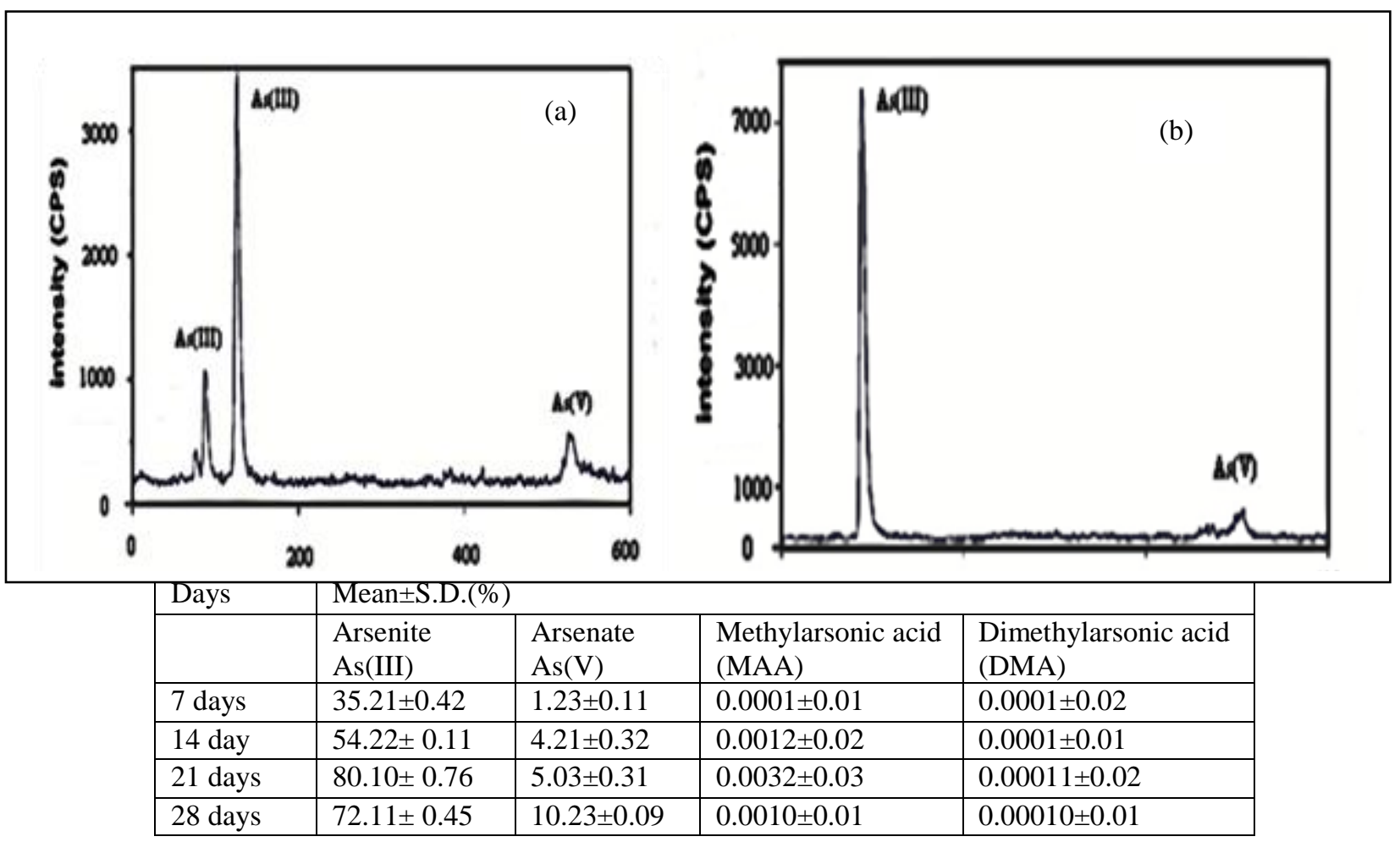

S.D. = Standard deviation

The standard deviation has been obtained for $n=3$

\subsection{Characterization Of Extract Material \\ 3.3.1. SEM-EDX Analysis}

The surface morphology of Vigna radiate root biomass without and with extract of arsenic ions during absorption process was observed with the help of SEM-EDX (JOEL model JSM-6480LV (Japan).) and presented in Figure 4a. It is show that the surface texture and pores in the species without absorption of arsenic ions. Figure $4 \mathbf{b}$ shows the morphological changes with respect to shape and size of the materials after absorption of arsenic ions respectively. It can be clearly observed that the surface of materials shape has been changed into a new shiny bulky particle and whitish patches structure. The EDX spectra of arsenic ions are shown in Figure.4a and Figure 4b. So, it was concluded that, arsenic ions were adsorbed on the surface of the extract materials. These results are further confirmed with the results of FTIR spectra analysis. 
International Journal of Research in Advent Technology, Vol.7, No.3, March 2019

E-ISSN: 2321-9637

Available online at www.ijrat.org

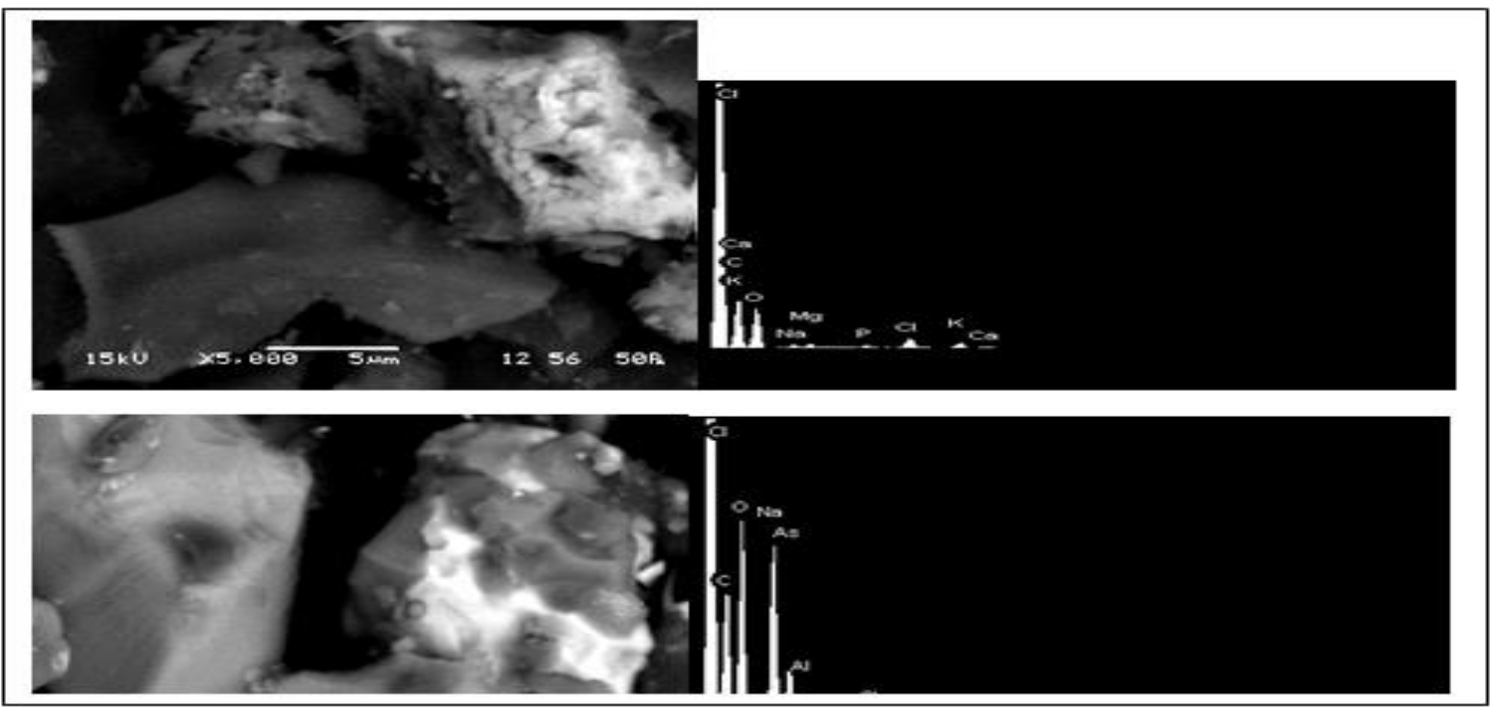

Figure 4. SEM-EDX images of Vigna radiate root biomass (a) without and (b) with absorption of arsenic ions.

\subsubsection{FTIR Analysis}

FTIR (Perkin Elmer FT-IR, Spectrometer Spectrum RX-I.) spectra of extract material of arsenic determine which functional groups may have contributed to the arsenic ions as shown in Figure 5. The spectra of extract material exhibit a broad absorption band at $3672.17 \mathrm{~cm}^{-1}$ due to bonded $-\mathrm{OH}$ stretching vibration which complexation of $-\mathrm{OH}$

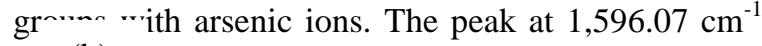
$\mathrm{m}$ (b) ue to the complexation of carboxylic group with arsenic ions [ 32-33]. The absorbance peaks at $1498.80 \mathrm{~cm}^{-1}$ and $1473.68 \mathrm{~cm}^{-1}$ attributed due to $\mathrm{N}-\mathrm{H}$ stretching vibration, $-\mathrm{CH}_{2}$ scissoring or $-\mathrm{CH}_{3}$ anti symmetrical bending vibration and $\mathrm{O}-\mathrm{H}$ deformation is shifted to lower frequency may be due to the complexation of arsenic ions. Another peak at $1,231.24 \mathrm{~cm}^{-1}, 1167.68 \mathrm{~cm}^{-1}, 1069.70 \mathrm{~cm}^{-1}$ and $1,022.57 \mathrm{~cm}^{-1}$ may be due the interaction of nitrogen from amino group with arsenic ions The other weak absorption peak $809.43 \mathrm{~cm}^{-1}$ to $751.50 \mathrm{~cm}^{-1}$ and $689.90 \mathrm{~cm}^{-1}$ corresponding to the thiol or sulfhydryl group with arsenic ions [34-35]. This clearly manifests the binding of arsenic ions to the extract materials.

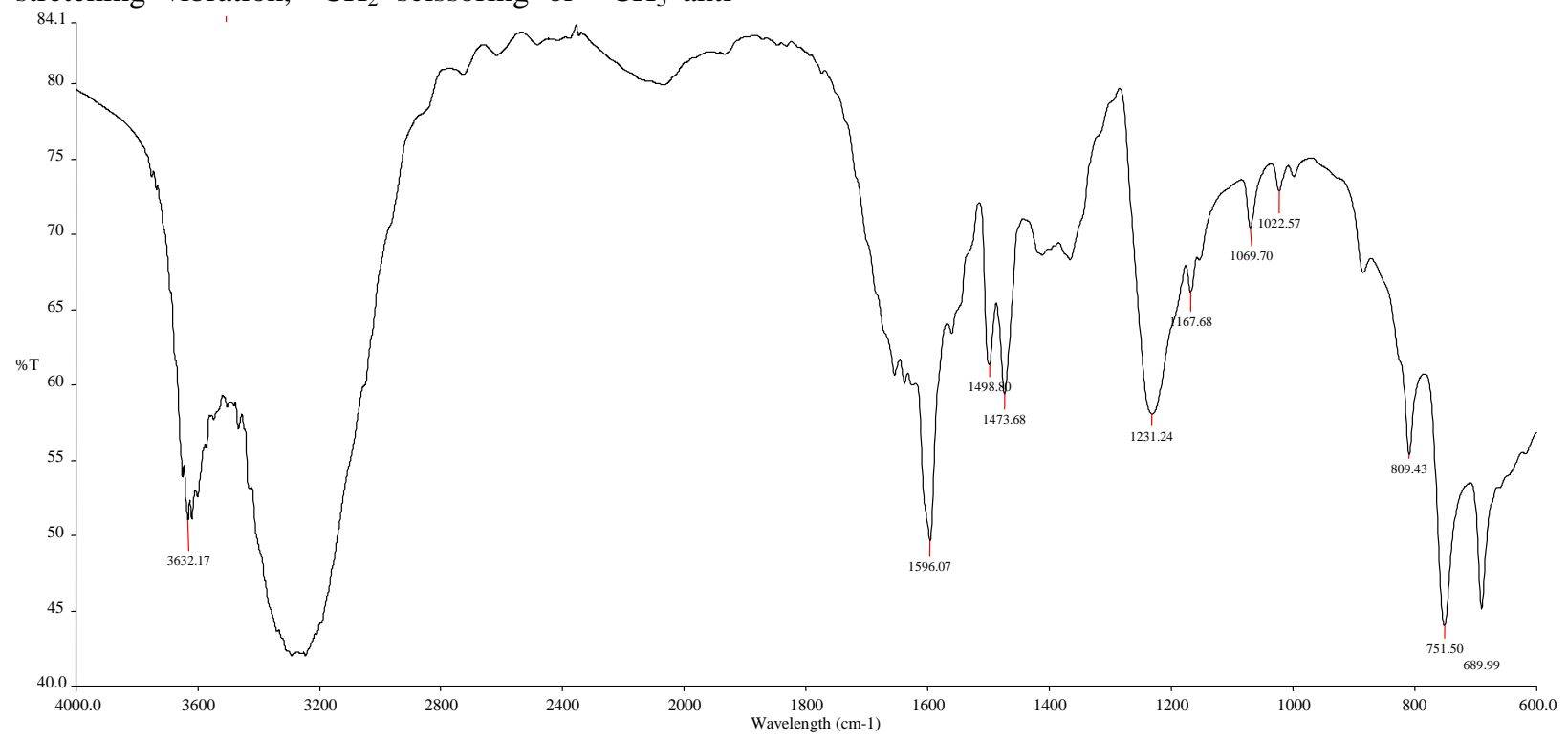

Fig. 5. FTIR spectra of arsenic ions absorption of extracted materials. 
International Journal of Research in Advent Technology, Vol.7, No.3, March 2019

\section{E-ISSN: 2321-9637 \\ Available online at www.ijrat.org}

\section{CONCLUSION}

Nutrient culture is an efficient method for screening toxic element tolerant capacity of Vigna radiate plant in aqueous solution treatment. The arsenic ions uptake is ascertained by using inductively coupled plasma mass spectroscopy. Maximum removal percentage of arsenite is $85.14 \%$ after 21 days' treatments using $10 \%(\mathrm{v} / \mathrm{v})$ tetramethylammonium hydroxide (TMAH) solution at $30{ }^{\circ} \mathrm{C}$ for 30 minutes. Arsenic ions species speciation using high performance liquid chromatography and arsenite ions were reveals maximum percentage among other arsenic species. Before and after accumulation of arsenic ions were characterized by SEM-EDX technique. The FTIR spectroscopic analysis confirmed that the $-\mathrm{OH}$ stretching vibration, complexation of carboxylic group, interaction of nitrogen from amino group and corresponding to the thiol or sulfhydryl group with arsenic ions. Great removal efficiency and high arsenic ions accumulation capacity make Vigna radiate is an excellent choice for phytoremediation processes.

\section{ACKNOWLEDGMENT}

The authors are thankful to Head of Department Environmental Science, Fakir Mohan University Balasore, Odisha, for necessary facilities and help in carry out the research work.

\section{REFERENCES}

[1] Hani, A. and Pazira, E. Heavy metals assessment and identification of their sources in agricultural soils of Southern Tehran, Iran. Envirn.Monit.Assess., 176 (14): 677- 691 (2011).

[2] Dogan, M. and Dogan, A. U. Arsenic mineralization, source, distribution, and abundance in the Kutahya region of the Westren Anatolia, Turkey. Environ. Geochem. Health, 29(2):119-129 (2007).

[3] Meharg, A. A. and Whitaker J. H. Arsenic uptake and metabolism in arsenic resistant and nonresistant plant species. New Phytologist, 154, 29-43 (2002).

[4] Zaw, M. and Emett, M.T. Arsenic removal from water using advanced oxidation process. Toxicol. Lett., 133:113-118 (2002).

[5] Smith, A. H., Lopipero, P. A., Bates, M.N. and Steinmaus, C. M. Arsenic epidemiology and drinking water standards. Science, 296 (21):2145-2146 (2002).

[6] Nigam, S., Gopal, K. and Vankar, P.S. Biosorption of arsenic in drinking water by submerged plant: Hydrilla verticilata.
Environ. Sci. Pollut. Res. Int., 20(6): 40004008 (2013).

[7] Misbahuddin, M. and Fariduddin, A. Water hyacinth removes arsenic from arseniccontaminated drinking water. Arch.

Environ. Health, 57(6): 516-519 (2002).

[8] Thomas, S.Y., Choong, T.G., Robiah, Y., Koay, F.L.G. and Azni, I. Arsenic toxicity, health hazards and removal techniques from water: an overview. Desalination, 217:139166 (2007).

[9] Wang, S. and Mulligan, C.N. Speciation and surface structure of inorganic arsenic in solid phases: a review. Environ. Int. 34: $867-$ 879 (2008).

[10] Mieke, Q., Zed, R. and Michael, S. Arsenic speciation in terrestrial plant material using microwave-assisted extraction, ion chromatography and inductively coupled plasma mass spectrometry. J. Anal. At.,Spectrom., 18: 128-134 (2003).

[11] Fayiga, A.O., Ma, L.Q., Santos, J., Rathinasabhapathi, B., Stamps, B. and Littell, R.C. Effects of arsenic species and concentrations on arsenic accumulation by different fern species in a hydroponic system. Int. J. Phytoremed. 7:231-240 (2005).

[12] Tangahu, B.V., Abdullah, S.R.S., Basri, H., Idris, M., Anuar, N. and Mukhlisim, M. A review on heavy metals $(\mathrm{As}, \mathrm{Pb}$, and $\mathrm{Hg}$ ) uptake by plants through phytoremediation. Int. J. of Chem. Eng., 1-31 (2011).

[13] Natarajan, S., Stamps, R. H., Saha, U. K. and $\mathrm{Ma}$, L. Q. Phytofiltration of arseniccontaminated groundwater using Pteris vittata L.: Effect of plant density and nitrogen and phosphorus levels. Int. J. Phytoremed. 10: 222-235 (2008).

[14] Singh, S.K., Juwarkar, A.A., Kumar, S., Meshram, J. and Fan, M. Effect of amendment on phytoextraction of arsenic by Vetiveria zizanioides from soil. Int. J. Environ. Sci. Tech., 4 (3): 339-344 (2007).

[15] Tu, S., Ma, L.Q., Fayiga, A.O. and Zillioux, J. Phytoremediation of arsenic contaminated ground water by the arsenic hyperaccumulating fern Pterisvittata L. Int. J. Phytoremed, 6 (1): 35-47 (2004).

[16] Mukhopadhyay, R., Shi, J. and Rosen, B.P. Purification and characterization of Acr2p, the Saccharomyces cerevisiae arsenate reductase. J. Biol Chem., 275: 21149-21157 (2000). 
International Journal of Research in Advent Technology, Vol.7, No.3, March 2019

E-ISSN: 2321-9637

Available online at www.ijrat.org

[17] Corseuil, H. X. and Moreno, F. N. Phytoremediation potential of willow trees for aquifers contaminated with ethanolblended gasoline. Water Res., 35(12):30133017 (2001).

[18] Chiu, K.K., Ye, Z.H. and Wong, M.H. Enhanced uptake of $\mathrm{As}, \mathrm{Zn}$ and $\mathrm{Cu}$ by Vetiveria zizanioides and Zea mays using chelating agents. Chemosphere, 60: 13651375 (2005).

[19] Wang, W.C. and Lewis, M. A. Metal accumulation by aquatic macrophytes. in: Plants for Environment Studies. (Edited by W. C. Wang, J. W. Gorsuch, J. S. Hughes,) 367-416.Lew is publishers, New York (1997).

[20] Giri, A.K. and Patel, R. K. Toxicity and bioaccumulation potential of $\mathrm{Cr}$ (VI) and $\mathrm{Hg}$ (II) on differential concentration by Eichhornia crassipes in hydroponic culture. Water Science \& Technology 63(5):899907(2011).

[21] Quaghebeur, M., Rengel, Z. and Michael, S. Arsenic speciation in terrestrial plant material using microwave-assisted

extraction, ion chromatography and inductively coupled plasma mass spectroscopy. J. Anal. At. Spectrom, 18:128-134 (2003).

[22] Amman, A. A. Inductively coupled plasma mass spectrometry (ICP MS): A versatile tool. Journal of Mass Spectrometry, 42:419-427 (2007).

[23] Winer, B. J. Statistical principles in Experimental Design. International Student Edition, London (1981).

[24] Chua, H. Bio-accumulation of environmental residues of rare earth elements in aquatic flora Eichhornia crassipes(Mart) Solms in Guangdong Province in China. The Science of the Total Environment, 214: 79-85 (1998).

[25] Ackley, K. L. Hymer, C. B. Sutton, K. L. and Caruso, J. A. Speciation of arsenic in fish tissue using microwave-assisted extraction followed by HPLC-ICP-MS. $J$. Anal. At. Spectrom, 14(5): 845-850 (1999).

[26] Heitkemper, D.T., Vela, N.P., Stewart, K.R. and Westphal, G.S. Determination of total and speciated arsenic in rice by ion chromatography and inductively coupled plasma mass spectrometry. J. Anal. At. Spectrom., 16:299-306 (2001).

[27] Whitaker, J.H., Woods, C. and Meharg, A. A. Is differential phytochelatin production related to decreased arsenate influx in arsenate tolerant Holcuslanatus?. New Phytol., 155(2): 219-225 (2002).

[28] Aydina, F.A. and Soylaka, M. Separation, preconcentration and inductively coupledplasma-mass spectrometric (ICPMS) determination of thorium(IV), titanium(IV), iron(III), lead(II) and chromium(III) on 2-nitroso-1- naphthol impregnated MCI GEL CHP20P resin. Journal of Hazardous Materials, 173(13):669-674 (2010).

[29] Ambushe, A.A., McCrindle, R.I. and McCrindle, C.M.E. Speciation of chromium in cow's milk by solid-phase extraction/ dynamic reaction cell inductively coupled plasma mass spectrometry (DRC-ICP-MS). Journal of Analytical Atomic Spectrometry, 24: 502-507 (2009).

[30] Delnomdedieu, M., Basti, M., Otvos, J.D. and Thomas, D.J. Reduction and binding of arsenate and dimethylarsinate by glutathione -a magnetic-resonance study. Chem Biol. Interact., 90 92): 139-155(1994).

[31] Saka, C. BET, TG-DTG, FT-IR, SEM, iodine number analysis and preparation of activated carbon from acorn shell by chemical activation with $\mathrm{ZnCl}_{2}$. Journal of Analytical and Applied Pyrolysis, 95:2124(2012).

[32] Bang, S., Patel, M., Lippincott, L. and Meng, X. Removal of arsenic from groundwater by granular titanium dioxide adsorbent. Chemosphere, 60:389-397 (2005).

[33] Balaji, T., Yokoyama, T., Matsunaga and Hideyuki. Adsorption and removal of As (V) and As (III) using Zr- loaded lysine diacetic acid chelating resin. Chemosphere, 59(8):1169-1174 (2005).

[34] Lim, S.F., Zheng, Y.M., Zou, S.W. and Chen, J.P. Uptake of arsenate by an alginate encapsulated magnetic sorbent: Process performance and characterization of adsorption chemistry. J. of Colloid and Interface Science, 333: 33-39 (2009).

[35] Jia, Y., Xu, L., Wang, X. and Demopoulos, G.P. Infrared spectroscopic and X-ray diffraction characterization of the nature of adsorbed arsenate on ferrihydrite. Geochim.Cosmochim. Acta 7:1643-1654 (2007). 